\title{
ANALISIS TERHADAP PELAKSANAAN PIDANA KEBIRI KIMIA DALAM KASUS KEKERASAN SEKSUAL PADA ANAK DALAM PERSPEKTIF YURIDIS DAN KEDOKTERAN
}

\author{
Debora Anggie Noviana \\ Universitas Pembangunan Nasional Veteran Jakarta \\ Jl. RS. Fatmawati Raya, Pondok Labu, Kec. Cilandak, Kota. Depok, Jawa Barat, 12450 \\ E-mail: deboraanggie73@gmail.com \\ Bambang Waluyo \\ Universitas Pembangunan Nasional Veteran Jakarta \\ Jl. RS. Fatmawati Raya, Pondok Labu, Kec. Cilandak, Kota. Depok, Jawa Barat, 12450 \\ E-mail: Bambangwaluyo@upnvj.ac.id \\ Rosalia Dika Agustanti \\ Universitas Pembangunan Nasional Veteran Jakarta \\ Jl. RS. Fatmawati Raya, Pondok Labu, Kec. Cilandak, Kota. Depok, Jawa Barat, 12450 \\ E-mail: Rosaliadika@upnvj.ac.id
}

\begin{abstract}
Abstrak
Pelaksanaan Kebiri Kimia merupakan hukuman yang baru di Indonesia, terjadi pro kontra terkait pelaksanaan tindakan tersebut, dari salah satu sisi pelaksanaan pidana kebiri diharapkan mampu memberikan efek jera bagi pelaku kekerasan seksual pada anak dan juga menjadi salah satu bentuk pencegahan agar tidak kembali terjadi kasus yang sama, serta diharapkan agar dapat mengurangi tingkat kejahatan seksual terhadap anak. Penelitian ini hendak mengkaji pelaksanaan kebiri kimia dilihat dari perspektif yuridis dan kedokteran. Metode penelitian yang digunakan adalah yuridis normatif. Pendekatan masalah dengan menggunakan pendekatan perundang-undangan dan pendekatan kasus, sumber utama berasal dari literatur serta menggunakan sumber data sekunder yang dianalisis secara kualitatif. Dengan masih banyaknya pro kontra yang terjadi terkait penerapan eksekusi kebiri kimia yang dikarenakan Ikatan Dokter Indonesia (IDI) menolak untuk melakukan eksekusi karena alasan kemanusiaan. Perlu adanya peraturan yang mengatur mengenai pelaksanaan eksekusi kebiri kimia agar dapat memberikan kepastian hukum dan keadilan baik bagi korban dan juga pelaku pelecehan seksual pada anak, dan juga memberikan dasar hukum yang sah bagi eksekutor kebiri kimia yaitu dokter untuk melakukan eksekusi kebiri kimia tersebut tanpa harus bertentangan dengan kode etik kedokteran sehingga pidana kebiri kimia dapat segera diberlakukan secara lebih efektif sesuai dengan tujuannya yaitu menggurangi angka kasus kekerasan seksual pada anak di Indonesia.
\end{abstract}

Kata Kunci : Kebiri Kimia, Perlindungan anak, Pidana 


\begin{abstract}
The implementation of castration chemistry is a new punishment in Indonesia, there are pros and cons related to the implementation of these actions, from one side of the implementation of castration criminal is expected to be able to provide a deterrent effect for perpetrators of sexual violence against children and also be a form of prevention so as not to reoccur the same case, and is expected to be able to reduce the level of sexual crimes against children. This study wants to examine the implementation of chemical castration from a juridical and medical perspective. The research method used is normative juridical. Approach the problem by using the legislative approach and case approach, the main source comes from the literature and uses secondary data sources that are analyzed qualitatively. With the many pros and cons that occur related to the implementation of chemical castration execution due to the Indonesian Doctors Association (IDI) refused to carry out executions due to humanitarian reasons. There is a need for regulations governing the implementation of chemical castration execution in order to provide legal certainty and justice for both victims and also perpetrators of sexual abuse on children, and also provide a legal basis for chemical castration executors namely doctors to carry out chemical castration execution without having to contradict with a code of ethics in medicine so that the chemical castration crime can be immediately applied more effectively in accordance with its goal of reducing the number of cases of sexual violence against children in Indonesia.
\end{abstract}

Keywords: Chemical castration, child protection, criminal

\title{
A. PENDAHULUAN
}

Kejahatan kesusilaan dan pelecehan seksual merupakan suatu jenis kejahatan yang bukan saja menjadi permasalahan dalam hukum nasional melainkan sudah menjadi permasalahan dalam hukum internasional yang juga banyak terjadi di negara-negara lainnya. ${ }^{1}$ Kejahatan kesusilaan dapat terjadi dan masih terus terjadi hingga saat ini karena beberapa faktor diantaranya karena korban dibawah ancaman dan membuat korban takut untuk melaporkan hal tersebut kepada pihak yang berwajib, korban tidak tahu bahwa perbuatan pelecehan seksual yang terjadi padanya adalah sebuah kejahatan terutama apabila korban masih anak-anak, atau hal-hal lain yang terkait dengan kemajuan teknologi yang membuat segala hal sangat mudah untuk ditemukan dan didapatkan, serta kurangnya perlindungan terhadap hal-hal apa saja yang dapat ditemukan dapat membuat seseorang memiliki kebebasan yang sangat bebas dan tidak jarang kebebasan tersebut disalah gunakan dan dijadikan sebagai alat untuk melakukan suatu kejahatan yang merugikan bagi orang lain. ${ }^{2}$

\footnotetext{
1 Sumera Marcheyla,April-Juni 2013," Perbuatan Kekerasan/Pelecehan Seksual Terhadap $\begin{array}{llllll}\text { Perempuan", Lex } & \text { et } & \text { Societatis, } & \text { Vol. } & \text { I, } & \text { No.2 }\end{array}$ https://ejournal.unsrat.ac.id/index.php/lexetsocietatis/article/viewFile/\%201748/1389, 30 September 2019 pukul 13.00 wib

2 Mardiya Nuzul Qur'aini, Maret 2017, "Jurnal Konstitusi Penerapan Hukuman Kebiri Kimia Bagi Pelaku Kekerasan Seksual Implementation of Chemical Castration PunishmentFor Sexual Offender", Pusat P4TIK Mahkamah Konstitusi RI, Volume 14, Nomor 1
} 
Kejahatan kesusilaan yang berawal dari pelecehan seksual, sering dianggap sebagai hal biasa atau lumrah terjadi dan kemudian berujung pada suatu kejahatan. Pelecehan seksual adalah penyalahgunaan hubungan antara perempuan dan laki-laki (dimana salah satu pihak dilecehkan martabatnya), dan pelecehan seksual ini tidak hanya dapat terjadi pada perempuan saja namun tidak menutup kemungkinan hal tersebut dapat pula terjadi pada laki-laki meskipun saat ini yang sering terjadi adalah pelecehan seksual dengan perempuan sebagai korbannya ${ }^{3}$. Masih marak terjadinya kasus kejahatan kesusilaan dan pelecehan seksual terjadi karena kurangnya pemahaman dan tingkat kepekaan masyarakat terhadap kasus-kasus seperti ini, dimana masyarakat sepakat berpendapat bahwa kasus-kasus seperti kejahatan kesusilaan dan pelecehan seksual ini hanya sebatas pada permasalahan yang terkait moralitas saja dan bukan merupakan suatu permasalahan yang memerlukan penanganan yang lebih serius jika dibandingkan dengan kasus-kasus lainnya seperti pembunuhan atau korupsi. Kasus mengenai kejahatan kesusilaan atau pelecehan seksual sendiri di masyarakat masih dianggap kurang penting untuk ditanggapi secara lebih serius, karena didukung juga dengan kurangnya pengertian dan materi yang dimuat dalam Kitab Undang-Undang Hukum Pidana (KUHP) yang secara lebih mendetail dan tegas mengenai hal-hal terkait kejahatan kesusilaan dan hanya menganggapnya sebagai sebuah pelanggaran terhadap kesusilaan

Hal-hal lain yang menjadi faktor terjadinya pelecehan seksual adalah adanya ketimpangan relasi kekuasaan antara pelaku dan korban dimana yang sering menjadi korbannya adalah perempuan, ketimpangan relasi kekuasaan yang dimaksud disini adalah dalam hal ketika salah satu pihak (pelaku) merasa bahwa dirinya memiliki kekuasaan yang lebih tinggi dibandingkan dengan pihak lainnya (korban) baik dalam bidang penguasaan sumber daya manusia, ekonomi, pengetahuan, dan status sosial yang kemudian menimbulkan kesewenangan yang dilakukan oleh salah satu pihak (pelaku) kepada pihak lainnya (korban). ${ }^{4}$

Pelaku pelecehan seksual tersebut sudah tidak hanya berasal dari orang yang memiliki golongan ekonomi rendah atau menengah, dan bukan juga hanya yang berasal dari orang yang memiliki tingkat pendidikan rendah atau bahkan tidak berpendidikan sama sekali, karena saat ini pelaku kejahatan kesusilaan tersebut sudah tidak memandang golongan ekonomi atau tingkat pendidikan. Sementara pihak yang sangat rawan untuk menjadi korban dalam kejahatan kesusilaan dan pelecehan seksual adalah perempuan dan anak-anak, karena berbagai alasan diantaranya

${ }^{3}$ Ibid.

4 Ibid.. 
karakteristik pribadi pelaku yang menyebabkan terjadinya kejahatan kesusilaan (faktor-faktor psikologis pelaku), karakteristik pribadi korban (faktor-faktor yang berasal dari diri korban yang membuat pelaku tertarik pada korban), masih banyaknya pandangan atau pendapat yang menyatakan bahwa kepentingan dan perspektif laki-laki adalah yang utama dan keberadaan atau kedudukan perempuan lebih rendah dan bahkan perempuan dipandang sebagai makhluk yang lemah jika dibandingkan dengan laki-laki. ${ }^{5}$

Seperti yang terjadi beberapa waktu yang lalu, seorang pelaku kekerasan seksual terhadap anak yang bernama Muh Aris yang berusia sekitar 20 tahun, telah melakukan kekerasan seksual atau pelecehan seksual pada sembilan orang anak dibawah umur. Ia ditangkap oleh pihak kepolisian pada oktober 2018 setelah pihak kepolisian mendapatkan laporan dari orangtua seorang bocah perempuan, yang merupakan korban dari perbuatan tak senonoh pelaku, dimana pelaku melakukan aksi kejinya tersebut setelah pelaku pulang ke rumah pelaku usai bekerja. Dalam perjalanan pulang itulah pelaku bertemu dengan korban yang sedang bermain sendirian di depan rumah korban. Pelaku yang merupakan pemuda asal Dusun Mengelo, Desa/Kecamatan Sooko, Kabupaten Mojokerto itu kemudian menarik secara paksa korban menuju ke sebuah rumah kosong yang berada tidak jauh dari rumah korban tersebut. Setelah dilakukan pemeriksaan diketahui pula bahwa pada saat yang bersamaan ketika pelaku membekap mulut korban disaat itu juga pelaku menjalankan aksinya yaitu melakukan kekerasan seksual pada korban, yang mengakibatkan alat kelamin bocah yang masih TK itu berdarah. Polisi kemudian dengan mudah menangkap pelaku setelah menemukan petunjuk melalui rekaman kamera pengawas yang berada di gang rumah korban. Perbuatan pelaku diancam dalam Pasal 76D jo Pasal 81 ayat (2) Undang-Undang RI Nomor 17 Tahun 2016 tentang Penetapan Peraturan Pemerintah Pengganti Undang-Undang Nomor 1 tentang Perubahan Kedua atas Undang-Undang RI Nomor 23 Tahun 2002 tentang Perlindungan Anak.

Seringnya pelecehan seksual terjadi pada anak, maka pemerintah mengambil sebuah langkah tegas untuk mencegah dan mengurangi tingkat kejahatan kesusilaan dan pelecehan seksual yang masih sering terjadi yaitu dengan mengeluarkan Peraturan Pemerintah Pengganti Undang-Undang (PERPU) Nomor 1 Tahun 2016 (untuk selanjutnya disebut sebagai PERPU Nomor 1 Tahun 2016) tentang amandemen kedua Undang-Undang Nomor 23 tahun 2002 tentang Perlindungan Anak. PERPU 1 Tahun 2016 kemudian disahkan menjadi Undang-Undang Nomor 17

5 Sumera Marcheyla,April-Juni 2013," Perbuatan Kekerasan/Pelecehan Seksual Terhadap Perempuan",LexetSocietatis,Vol.I,No.2 https://ejournal.unsrat.ac.id/index.php/lexetsocietatis/article/viewFile/\%201748/1389, 30 September 2019 pukul 15.00 wib. 
Tahun 2016 tanggal 9 November 2016 tentang diberlakukannya Undang-Undang tentang Perp Nomor 1 Tahun 2016, tentang amandemen kedua Undang-Undang Nomor 23 Tahun 2002 tentang Perlindungan Anak dalam Undang-Undang (selanjutnya disebut Undang-undang Perlindungan Anak) yang mengatur pembobotan hukuman bagi orang yang telah melakukan kejahatan seksual terhadap anak-anak, yaitu: hukuman mati, hukuman penjara seumur hidup, serta hukuman penjara hingga 20 tahun dan kejahatan tambahan berupa pengumuman identitas para penjahat. Selain itu, penjahat juga dapat dikenakan tindakan dalam bentuk pengebirian kimia dan pemasangan detektor elektronik.

Dalam kasus yang disebutkan diatas Hakim menjatuhkan hukuman tambahan yaitu berupa pidana kebiri kimia pada pelaku, pemberian pidana kebiri kimia ini didasarkan pertimbangan bahwa perbuatan pelaku telah memenuhi unsur-unsur yang termuat dalam Pasal 76D jo Pasal 81 ayat (2) Undang-Undang Perlindungan Anak. selain itu dengan jumlah korban lebih dari 1 (satu) maka perbuatan pelaku tergolong dalam Pasal 81 ayat (5) Undang-Undang Perlindungan Anak sehingga dapat dikenai tambahan kebiri kimia sebagaimana termuat dalam Pasal 81 ayat (7) UndangUndang Perlindungan Anak. Menurut penulis, langkah yang diambil oleh hakim dengan memutus pidana tambahan yaitu dengan menjatuhkan pidana kebiri kimia telah sangat tepat, karena dengan dijatuhkannya pidana kebiri kimia tersebut diharapkan dapat memberikan efek jera bagi pelaku pelecehan seksual pada anak dan juga guna mengurangi angka kasus pelecehan seksual pada anak.

Kebiri adalah tindakan bedah dan/atau penggunaan bahan-bahan kimia dengan tujuan untuk menghilangkan fungsi dari organ reproduksi testis (pada lakilaki) dan ovarium (pada perempuan). Kebiri sendiri terbagi menjadi 2 (dua) yaitu kebiri fisik dan kebiri kimia, kebiri fisik adalah tindakan bedah dengan mengangkat secara keseluruhan organ reproduksi testis (pada laki-laki) dan ovarium (pada perempuan). Kebiri kimia adalah tindakan penyuntikan hormon anti-testoteron kedalam tubuh pelaku dengan cara kerja menekan produksi dan aktivitas hormon testoteron sehingga mampu mengurangi libido orang yang berada dalam pengaruh obat tersebut. ${ }^{6}$

Hal tersebut membuat banyak pro dan kontra dikalangan kedokteran karena beberapa hal yang dianggap bertendangan dengan kode etik kedokteran dan sumpah profesi kedokteran, diantaranya dalam kode etik kedokteran menyatakan bahwa setiap tindakan yang diambil oleh seorang dokter yang melemahkan daya tahan psikis maupun fisik pasien wajib mendapatakan persetujuan dari pasien tersebut sedangkan dalam pelaksanaan eksekusi dari tindakan kebiri kimia tidak mungkin untuk meminta

${ }^{6}$ Soetedjo,dkk, 2 Jun 2018, "Jurnal Etika Kedokteran Indonesia Tinjauan Etika Dokter sebagai Eksekutor Hukuman Kebiri", Vol 2, No. 2. 
persetujuan pelaku sebagai pasien secara terlebih dahulu. Hal lain yang menjadi perdebatan diantaranya adalah terkait dengan masalah efektifitas dan efek samping yang ditimbulkan dari proses penyuntikan bahan kimia kedalam tubuh pelaku yang dianggap kurang efektif dan dapat menimbulkan permasalahan lainnya seperti permasalahan terkait kejiwaan yang kemungkinan dapat menimbulkan jenis kejahatan seksual lainnya dan bahkan bisa jauh lebih sadis. Pengenalan pengebirian bahan kimia adalah hukuman baru di Indonesia, ada pro dan kontra terkait dengan pelaksanaan tindakan ini. Di satu sisi, dengan adanya kebiri kimia ini diharapkan dapat membuat efek jera bagi pelaku sehingga mengurangi tingkat kekerasan seksual terhadap anak, serta mengurangi tingkat kejahatan seksual terhadap anak-anak. Namun di sisi lain, pengenalan pengebirian kimia dianggap sebagai pelanggaran hak asasi manusia (HAM). Sebenarnya, hak asasi manusia adalah hak paling mendasar yang dimiliki semua orang sebagai hadiah tertinggi dari Tuhan Yang Mahakuasa, di mana pun orang tinggal, karena dengan hak-hak ini manusia dapat menjadi makhluk yang berharga. Tetapi seperti yang telah dimuat dalam Pasal 28 J Ayat (2) UUD NRI Tahun 1945 yang berbunyi "Dalam menjalankan hak dan kebebasannya, setiap orang wajib tunduk kepada pembatasan yang ditetapkan dengan Undang-Undang dengan maksud semata-mata untuk menjamin pengakuan serta penghormatan atas hak dan kebebasan orang lain dan untuk memenuhi tuntutan yang adil sesuai dengan pertimbangan moral, nilai-nilai agama, keamanan, dan ketertiban umum dalam suatu masyarakat demokratis". Dari latar belakang masalah diatas dan juga masih banyaknya pro dan kontra terkait proses eksekusinya, maka rumusan masalah terkait dengan latar belakang tersebut yaitu mengenai bagaimana penerapan eksekusi kebiri kimia dalam kaitannya dengan kode etik dan sumpah jabatan dokter.

\section{B. METODE PENELITIAN}

Penulis melakukan penelitian dengan menggunakan jenis penelitian hukum normatif (yuridis normatif), yaitu penelitian hukum doktriner, juga disebut sebagai penelitian perpustakaan atau studi dokumen.. ${ }^{7}$ Jenis pendekatan masalah yang digunakan oleh penulis dalam melakukan penelitiannya adalah melalui pendekatan hukum teoritis yakni pendekatan Undang-Undang dan peraturan yang terkait didalamnya, yang dilakukan dengan cara menelaah semua peraturan-peraturan baik yang dalam bentuk perundang-undangan maupun peraturan dibawahnya yang terkait dengan permasalah yang akan diteliti oleh penulis. Selain itu peneliti juga menggunakan jenis pendekatan masalah melalui pendekatan hukum kasus yakni pendekatan terhadap kasus-kasus yang berkaitan dengan isu hukum yang dihadapi dengan cara menelaah kasus-kasus yang telah diputus oleh pengadilan dan telah

7 Bambang Waluyo, 2002, "Penelitian Hukum Dalam Praktek", Jakarta, Sinar Grafika, Edisi 1 Cetakan 3 halaman 13-halaman 14 
memiliki kekuatan hukum tetap dan yang akan dipelajari atau diteliti adalah mulai dari hal-hal yang menjadi dasar pertimbangan Hakim hingga dapat membuat suatu keputusan yang dimana putusan tersebut akhirnya membuat suatu isu hukum. Penelitian ini adalah penelitian hukum normatif atau penelitian hukum kepustakaan, yaitu penelitian yang dilakukan dengan cara meneliti bahan pustaka atau data sekunder belaka. Adapun data sekunder mencakup :

1. Bahan hukum primer, yang terdiri dari Peraturan Perundang-Undangan dalam hal ini berupa: Kuhp, Undang-Undang Republik Indonesia Nomor 17 Tahun 2016 Tentang Penetapan Peraturan Pemerintah Pengganti Undang-Undang Nomor 1 Tahun 2016 Tentang Perubahan Kedua Atas Undang-Undang Nomor 23 Tahun 2002 Tentang Perlindungan Anak Menjadi Undang-Undang dan peraturan lain yang terkait.

2. Bahan hukum sekunder, yang memberikan penjelasan mengenai bahan hukum primer, seperti, karya-karya tulis dari kalangan hukum, pendapat para pakar hukum. Bahan hukum yang terkumpul kemudian diolah dan dianalisis secara normatif kualitatif. ${ }^{8}$

\section{DISKUSI DAN PEMBAHASAN}

\section{Penerapan Eksekusi Kebiri Kimia Dalam Kaitannya dengan Kode Etik dan Sumpah Jabatan Dokter}

Banyak pihak yang menilai pidana kebiri terlalu keji dan tidak manusiawi, tidak mendidik, serta merendahkan derajat dan martabat manusia. Ada juga yang berpendapat pidana kebiri diberlakukan karena desakan masyarakat sehingga beraroma dendam dan subyektif. Terakhir muncul penolakan dari dokter, dalam hal ini Ikatan Dokter Indonesia (IDI), untuk menyuntik pelaku pedofil dengan zat kimia. Dokter menolak menjadi eksekutor pidana kebiri dengan alasan bertentangan dengan kode etik (KODEKI). Sesuai kode etik, seorang dokter harus menjadi pelindung kehidupan sesuai dengan Pasal 11 Kode Etik Kedokteran. Seorang dokter harus mengerahkan segala kemampuanya untuk memelihara kehidupan alamiah pasienya dan tidak untuk mengakhirinya.

Sekretaris Jenderal Pengurus Besar IDI Adib Khumaidi mengatakan, eksekusi kebiri kimia bertentangan dengan sumpah, etika, dan disiplin kedokteran yang berlaku internasional. Sikap IDI tetap sama, bukan menolak hukumannya tapi IDI menolak sebagai eksekutornya, karena melanggar sumpah dan etika kedokteran. Adib menjelaskan, disiplin dan etika kedokteran ini melekat pada profesi dokter di mana saja. Dokter-dokter yang tak bergabung dengan IDI juga terikat dengan etika ini, begitu pula dokter kepolisian dan militer. Profesi dokter itu melekat, di banyak pihak yang menilai pidana kebiri terlalu keji dan tidak manusiawi, tidak mendidik, serta

\footnotetext{
${ }^{8}$ Soerjono Soekanto,dkk,2003" Penelitian Hukum Normatif; Suatu Tinjauan Singkat",Jakarta, PT Raja Grafindo Persada, halaman 13
} 
merendahkan derajat dan martabat manusia. Menyambung kontroversi penetapan Undang-Undang Nomor 17 Tahun 2016 tentang Perlindungan Anak, kontroversi lain kemudian timbul terkait penolakan Ikatan Dokter Indonesia (IDI) untuk menjadi eksekutor hukuman kebiri bagi pelaku kejahatan seksual pada anak. ${ }^{9}$ Undang-Undang tersebut, dicantumkan metode hukuman kebiri berupa injeksi zat kimia antiandrogen dan bertujuan untuk mengurangi produksi hormon testosteron sehingga menurunkan dorongan seksual terpidana untuk sementara. Dalam pelaksanaannya, prosedur kebiri melibatkan risiko timbulnya rasa sakit dan komplikasi lainnya pada terpidana. Untuk itu, Dokter dianggap sebagai profesi yang tepat untuk dijadikan eksekutor hukuman kebiri karena kompetensi yang dimilikinya, dibandingkan dengan profesi lainnya.

Di sisi lain, profesi kedokteran yang berpegang pada prinsip kedokteran berbasis bukti menilai bahwa efektivitas kebiri kimia sejatinya masih menjadi pertanyaan karena belum adanya studi double blind yang adekuat untuk membuktikan efektivitasnya. Hal ini kemudian menjadi landasan sikap IDI yang menolak keterlibatan dokter sebagai eksekutor kebiri. Penolakan IDI tersebut disampaikan melalui fatwa Majelis Kedokteran Etik Kedokteran (MKEK) Nomor 1 Tahun 2016 tentang Kebiri Kimia. ${ }^{10}$ Selain efektivitas kebiri, berbagai alasan lainnya turut mendasari penolakan IDI tersebut, seperti berbagai efek samping yang tidak diinginkan dari kebiri, kemungkinan permasalahan kejiwaan (psikis) yang menyebabkan kejahatan seksual, dan kesempatan bagi terpidana untuk melakukan tindak kriminal yang lebih ekstrem. ${ }^{11}$

Dalam Kode Etik Kedokteran (KODEKI) Tahun 2012 Pasal 5 menyatakan bahwa "setiap perbuatan/nasihat dokter yang mungkin melemahkan daya tahan psikis maupun fisik, wajib memperoleh persetujuan pasien/keluarganya dan hanya diberikan untuk kepentingan dan kebaikan pasien tersebut". Pada penjelasan pasal diterangkan bahwa melemahkan psikis maupun fisik pasien bertentangan dengan fitrah ilmu kedokteran kecuali bila terdapat alasan pembenar dari tindakan tersebut, seperti prosedur penghilangan fungsi saraf yang digunakan dalam pembiusan prabedah dan pemberian obat anti nyeri pada pasien dengan nyeri tak tertahankan. ${ }^{12}$

Mengacu pada hal tersebut, selain dari tindakan yang bertujuan menyembuhkan pasien, menghilangkan fungsi tubuh normal pasien bertentangan

9 Tisnadibrata IL. IDI tolak hukum kebiri [Internet]. Jakarta; 2016 [disitasi 2018 Apr 5].

10 Pengurus Besar Ikatan Dokter Indonesia. Fatwa Majelis Kehormatan Etik Kedokteran Indonesia nomor 1 tahun 2016.

${ }^{11}$ Rachmaningtyas A. Tugas dokter menyembuhkan alasan IDI tolak hukuman kebiri dinilai wajar [Internet]. Jakarta; 2016 [disitasi 2018 Apr 5].

12 Majelis Kehormatan Etik Kedokteran Indonesia. Kode etik kedokteran tahun 2012. Jakarta; 2012 
dengan tugas seorang dokter. Hal ini kemudian berlaku pada prosedur hukuman kebiri. Kendati bertujuan untuk kebaikan masyarakat luas dan pengendalian dorongan hormon seksual yang berlebihan pada pelaku kejahatan seksual, dalam hakikatnya mencederai fungsi normal tubuh pasien tetap tidak dapat dikatakan bebas dari pelanggaran terhadap etika kedokteran.

Meskipun demikian, bila Dokter lepas tangan dalam hal ini, pertanyaan selanjutnya siapakah yang harus menggantikan peran dokter sebagai profesi dengan kompetensi yang mampu mengerti kesehatan fisik maupun psikis pasien dalam rangka mengurangi rasa sakit yang harus diderita oleh pelaku. Seorang eksekutor yang telah diberikan pelatihan kompetensi khusus kebiri kemudian menjadi salah satu jawaban untuk menengahi kepentingan antara hukum dan etika kedokteran.

Terkait penerapan tindakan kebiri kimia yang diatur dalam Undang-Undang Perlindungan Anak muncul pendapat berbeda dinyatakan oleh para tenaga medis. Menurut Ketua Bagian Andrologi dan Seksologi Fakultas Kedokteran Universitas Udayana, Denpasar, Wimpie Pangkahila, pada era modern, kebiri memang tak lagi dilakukan dengan membuang testis, tetapi secara kimia. Prosesnya bisa melalui pemberian pil ataupun suntikan hormon anti-androgen. Kebiri secara kimiawi dapat merusak bahkan menggerogoti fungsi organ, yakni pengecilan fungsi otot, osteoporosis, mengurangi jumlah sel darah merah, dan mengganggu fungsi organ kognitif lainnya. Menurutnya, sejauh ini tidak ada data yang mendukung apabila penerapan kebiri secara kimiawi bisa memberi efek jera lebih dari hukuman yang ada. ${ }^{13}$

Menurut Arry Rodjan, seorang urolog, biaya untuk menyediakan suntikan kebiri kimiawi sebesar Rp. 700.000,00 - Rp. 1.000.000,00 untuk sekali pemakaian, dan efek suntikannya dapat bertahan dari 1 - 3 bulan. Menurutnya, biaya tersebut mahal dan tidak efektif. ${ }^{4}$

Ketua Majelis Kehormatan Etik Kedokteran (MKEK) Pusat, Prijo Sidipratomo mengatakan Dokter menolak menjadi eksekutor kebiri karena sangat bertentangan dengan kode etik. Sesuai kode etik, seorang Dokter harus menjadi pelindung kehidupan sesuai Pasal 11 Kode Etik Kedokteran. Hal lain yang akan menjadi ganjalan, seorang dokter bertindak harus dengan inform consent atau persetujuan tindakan medis dari pasien atau keluarganya, Tanpa itu Dokter tidak bisa melakukan tindakan medis. ${ }^{15}$

\footnotetext{
${ }^{13}$ (http://www.idionline.org/page/4/?s=kebiri)

14 http://forumkeadilan.co/hukum/10-alasan-hukuman-kebiri-tidak-efektif-bagi-pelakukejahatan-seks/)

15 http://www.antaranews.com/berita/566611/wapres-menghormati-keputusan-idi-tolakeksekusi-kebiri
} 
Selain itu dari Ikatan Dokter Indonesia (IDI) juga menyatakan penolakannya menjadi eksekutor hukuman kebiri bagi pelaku kejahatan seksual kepada anak-anak. Hal ini menurut IDI dikarenakan pelaksanaan hukuman kebiri oleh dokter dianggap melanggar Sumpah Dokter dan Kode Etik Kedokteran Indonesia. Dalam menegakkan keadilan, khususnya kasus paedofilia atau pemerkosaan anak yang sangat brutal terhadap kemanusiaan dan cenderung berulang, Hakim dapat menambahkan hukuman kebiri kimia. Sehubungan dengan tugas, fungsi dan wewenang tenaga medis atau kesehatan (Dokter) yang adalah penyembuhan dan penghormatan hidup manusia secara alami, maka organisasi profesi telah mengeluarkan fatwa MKEK PB IDI Nomor 1 Tahun 2016 yang pada prinsipnya bahwa tugas yang bertentangan dengan penyembuhan adalah bukan tugas profesi dokter.

Bila Hakim benar-benar memutuskan hukuman tambahan berupa kebiri kimia, maka tugas tersebut agar diperankan eksekusinya oleh pihak yang berwenang sebagai eksekutor seperti pada lazimnya Ilmu kedokteran sangat memuliakan kesehatan siapa pun sebagai hak asasi manusia, karenanya para dokter harus menyadari tugasnya untuk mencegah, mendiagnosis, dan mengobati penyakit. Dengan demikian profesi kedokteran dapat tetap menghormati keputusan hukum yang ada tanpa harus mencederai sumpah profesinya.

Atas dasar keilmuan dan bukti-bukti ilmiah, kebiri kimia tidak menjamin hilang atau berkurangnya hasrat serta potensi perilaku kekerasaan seksual pelaku," ujar Ketua Majelis Pengembangan Profesi Kedokteran (MPPK) IDI, Pudjo Hartono dalam keterangan resminya pada awal pekan ini. ${ }^{16}$

Ketua Majelis Pengembangan Profesi Kedokteran (MPPK) IDI bernama Pudjo Hartono menyatakan bahwa, penunjukan dokter sebagai eksekutor hukuman itu juga bertentangan dengan fatwa Majelis Kehormatan dan Etik Kedokteran (MKEK) Nomor 1 Tahun 2016 tentang Kebiri Kimia sekaligus prinsip dalam Kode Etik Kedokteran Indonesia (KODEKI).

IDI juga mengusulan penegak hukum mencari bentuk hukuman lain sebagai sanksi tambahan. MPPK IDI tetap mendorong keterlibatan Dokter dalam hal rehabilitasi korban dan pelaku. Rehabilitasi korban menjadi prioritas utama guna mencegah dampak buruk dari trauma fisik dan psikis yang dialaminya.

\section{Pendapat Para Ahli Dalam Pelaksanaan Kebiri Kimia dan Penyelesaiannya menurut KUHP}

Hukuman kebiri kimia menjadi sorotan setelah Pengadilan Negeri (PN) Mojokerto memutuskan memberi pidana tambahan kepada pelaku kekerasan seksual terhadap anak yaitu Muhammad Aris (20), Mojokerto, Jawa Timur. "Hakim Pengadilan

16 (tirto.id Fadiah Alayidrus, 27 Agustus 2019) 
Negeri (PN) Mojokerto memutuskan pelaku bersalah melanggar Pasal 76 D juncto Pasal 81 ayat (2) UU RI nomor 23 tahun 2002 tentang Perlindungan anak. Vonis tersebut tertuang dalam Putusan PN Mojokerto nomor 69/Pid.sus/2019/PN.Mjk tanggal 2 Mei 2019. Para ahli berpendapat sebagai berikut:

1. Yusron Marzuki,

Eksekusi hukuman kebiri kimia terpidana yang sudah ditetapkan dalam amar putusan Hakim, wajib dilaksanakan oleh eksekutor. Eksekutornya adalah jaksa, namun karena jaksa tidak memiliki pengetahuan medis, maka bisa minta bantuan dokter. Bagi Kejaksaan, putusan ini sudah menjadi norma dan sudah mengikat. Maka sebagai eksekutor, jaksa punya kewajiban untuk melaksanakan. ${ }^{17}$

Yusron menilai, penerapan hukuman kebiri kimia memberikan kepastian hukum atas tindakan pelaku. Hal ini bukan berarti dapat memberikan efek jera atau efektif tetapi lebih kepada kepastian hukum.

Terkait dengan pelaksanaan teknis hukuman kebiri kimia, Yusron menyatakan, telah diatur dalam Perpu Nomor 1 Tahun 2016 tentang Perubahan Kedua atas Undang-Undang Nomor 23 Tahun 2002 tentang Perlindungan Anak (diubah dengan UU nomor 35 tahun 2014 TENTANG PERUBAHAN ATAS UNDANG-UNDANG NOMOR 23 TAHUN 2002 TENTANG PERLINDUNGAN ANAK). Ia menuturkan, Perpu itu, pada Pasal $81 \mathrm{~A}$, mengatur tentang kapan waktu pelaksanaan kebiri kimia harus dilakukan. Pasal 81 A menyebut "Tindakan sebagaimana dimaksud dalam Pasal 81 ayat (7) dikenakan untuk jangka waktu paling lama 2 (dua) tahun dan dilaksanakan setelah terpidana menjalani pidana pokok. ${ }^{18}$ Pelaksanaan hukuman tambahan kebiri ini, baru dapat dilaksanakan, kalau si terpidana selesai menjalani pidana pokoknya. Setelah itu, baru dilaksanakan hukuman tambahan, yakni kebiri kimia, dengan ancaman maksimal 2 tahun".19 Yusron juga berpendapat jika Dokter yang diminta jaksa menolak melaksanakan eksekusi kebiri kimia karena bertentangan dengan prinsip maupun keilmuan kedokteran, pada prinsipnya tidak ada seorang warga negara pun yang dapat menolak Undang-Undang atau aturan negara. Karena aturan dalam Undang-Undang telah "memerintahkan", semua orang dianggap tahu dan wajib melaksanakan perintah Undang-Undang tersebut. Namun, tidak menutup kemungkinan, jika dokter tidak setuju dan berencana "melawan" perintah Undang-Undang tersebut, dapat menyalurkannya sesuai dengan jalur

\footnotetext{
17 Ibid

${ }^{18}$ Liputuan6.com, Senin, 26 Agustus 2019.

${ }^{19}$ Ibid
} 
konstitusi. ${ }^{20}$ Dokter harus tunduk dan patuh terhadap hukum negara. Kalau dokter tidak setuju atau menolak hukuman kebiri, jalannya bisa melalui judicial review ke Mahkamah Konstitusi (MK). Tapi prinsipnya, semua pihak wajib melaksanakan aturan Undang-Undang, tidak bisa menolak. Jaksa dianggapnya masih memiliki waktu yang cukup panjang, sambil mempersiapkan perangkat teknis eksekusi. Hal ini mengingat belum ada Peraturan Pemerintah (PP) untuk eksekusi terkait hukuman kebiri kimia

2. Agus Purwadianto

Kebiri kimia adalah tindakan medis. Oleh karena itu perlu ada perlakuan yang mengikuti prosedur medis dalam pelaksanaan sanksi kebiri. Dokter tidak bisa hanya sekadar menjadi pelaksana pengebirian seperti regu tembak saat menjadi algojo eksekusi hukuman mati."

Ia mengatakan bahwa ada prosedur yang biasanya dilakukan kepada pasien juga harus diberikan kepada terpidana yang akan dijatuhi sanksi kebiri kimia. Apalagi Agus menemukan sejumlah studi yang menunjukkan bahwa sanksi kebiri di negara lainnya dilakukan pada pelaku kejahatan seksual kategori tertentu. Studi tersebut menunjukkan hanya pelaku kejahatan seksual dengan motivasi seksual parafilia yang akan dijatuhi sanksi kebiri kimia. Kondisi parafilia adalah berbuat kejahatan karena motivasi kuat dari fantasi seksual. Misalnya pelaku pedofilia, masokis, fetis, ekshibisionis serta bentuk parafilia lainnya.

Sayangnya tidak ada kejelasan soal teknis penjatuhan sanksi kebiri kimia mulai dari tuntutan dari jaksa hingga vonis oleh hakim. Hingga saat ini masih belum ada peraturan pelaksana untuk memandu teknis eksekusi sanksi kebiri kimia. IDI masih menolak terlibat dalam penjatuhan sanksi kebiri kimia atas dasar larangan kode etik profesi kedokteran. Sebagai dokter yang juga sarjana hukum, Agus menilai ada persoalan serius yang harus dituntaskan kalangan dokter bekerja sama dengan ahli hukum berkaitan sanksi kebiri ini. Ia mengakui munculnya norma hukum berupa sanksi kebiri telah melalui sejumlah pertimbangan sosiologis dan yuridis. Faktanya pun sudah ada norma hukum yang mengikat soal kebiri kimia.

\section{Pandangan Hak Asasi Manusia (HAM) Terhadap Kebiri Kimia}

Hak asasi manusia adalah suatu materi yang sangat melekat pada hakekat dan hidup manusia, hak hak-hak manusia itu sejarahnya bisa ditelusuri sampai pada saat permulaan kisah manusia dalam pergaulan hidupnya di dunia ini, yaitu pada mulai sadar akan kedudukannya sebagai subyek hukum. Akan tetapi menurut ilmu pengetahuan, sejarah hak-hak manusia itu baru tumbuh dan berkembang pada waktu

${ }^{20}$ Ibid 
hak-hak asasi manusia itu oleh manusia mulai dipertahankan dan diperjuangkan terhadap serangan atau bahaya yang timbul dari kekuasaan yang dimiliki oleh bentukan masyarakat yang dinamakan Negara. Maka pada hakekatnya persoalan mengenai hakhak asasi manusia itu adalah berkisar pada perhubungan antara manusia (individu) dan masyarakat. ${ }^{21}$

Negara menjamin setiap anak berhak atas kelangsungan hidup, tumbuh dan berkembang serta berhak atas perlindungan dari kekerasan dan diskriminasi. Saat ini banyaknya terjadi kasus kekerasan seksual terhadap anak dibawah umur. Pemerintah memahami bahwa masalah kejahatan seksual terhadap anak sudah mencapai titik luar biasa dan memahami pula perlu diambilnya langkah yang luar biasa untuk mengatasi masalah tersebut, oleh sebab itu pemerintah mengeluarkan aturan baru yang diharapkan mampu memberikan efek jera kepada pelaku. Pada tahun 2016, Pemerintah mengeluarkan Perpu No 1 Tahun 2016, perpu ini memperberat bagi pelaku kejahatan seksual yang dimana dalam aturan tersebut terdapat pemberian sanksi hukum kebiri kimia bagi pelaku. Pasal tersebut disebutkan secara tegas bahwa untuk ancaman hukuman bagi pelanggar ketentuan pada Pasal 81 ayat 7 "Terhadap pelaku sebagaimana dimaksud pada ayat (4) dan ayat (5) dapat dikenai berupa kebiri kimia dan pemasangan alat pendeteksi elektronik".

Kebiri kimia merupakan suatu tindakan penyuntikan zat anti-testosteron ke tubuh pria untuk menurunkan kadar hormon testosteron, Testosteron itu adalah hormon yang berperan dalam beragam fungsi, salah satunya fungsi seksual. Artinya, hormon testosteron berpengaruh pada gairah seksual seorang pria.

Ketua Bagian Andrologi dan Seksologi Fakultas Kedokteran Universitas Udayana, Denpasar, Wimpie Pangkahila mengungkapkan, kebiri dalam dunia kedokteran dikenal dengan kastrasi. Kebiri tidak lagi dilakukan dengan membuang testis tetapi dapat secara kimia. Prosesnya bisa melalui pemberian pil ataupun suntikan anti andarogen. Hormon antiandrogen itu adalah anti-hormon laki-laki, pemberian obat antiandrogen itu akan membuat pria kekurangan hormon testosteron sehingga tak ada lagi memiliki dorongan seksual. Obat antiandrogen akan memberikan efek yang sama dengan kebiri fisik. ${ }^{22}$

Laporan world rape statistic tahun 2012 menunjukkan bahwa hukuman kebiri bagi pelaku tindak pidana perkosaan di berbagai Negara di dunia tidak efektif menimbulkan efek jera. Tidak ada bukti yang menjamin bahwa penggunaan kebiri kimia telah mengurangi jumlah kekerasan terhadap perempuan dan anak. ${ }^{23}$

\footnotetext{
${ }^{21}$ Susanto, S. \& Sukinta. (2006), Hukum dan HAM. Semarang, h. 18

${ }^{22}$ Maharani, Dian. (2015 Oktober 22). Yang Terjadi Jika Seseorang Dihukum Kebiri. Kompas.com

23 Nuzul Qur'aini Mardiya, (2017), Penerapan Hukuman Kebiri Kimia Bagi Pelaku KekerasanSeksual, Pusat P4TIK Mahkamah Konstitusi RI, 14
} 
Hukuman kebiri kimia seakan telah melanggar hak asasi manusia. Menurut Kepala Bagian Psikologi Klinis Fakultas Psikologi Universitas Katolik Indonesia Atma Jaya Jakarta, Dinastuti, efek (psikologis) kebiri fsik ataupun kimiawi tidak sama pada setiap orang. Kondisi ini membuat sanksi kebiri menimbulkan prokontra, termasuk di negara-negara maju. Perdebatan bukan hanya soal hak asasi manusia untuk tidak menyiksa dalam pemberian sanksi, melainkan juga ketidaksambungan antara penyebab seseorang melakukan kejahatan seksual dan bentuk hukumannya. Oleh karena itu, wajar jika suntik kebiri tidak terbukti mampu menekan kasus kejahatan seksual. ${ }^{24}$

Dilihat dari segi dunia kesehatan, pelaksanaan Hukum kebiri justru banyak menimbulkan efek negatif. Sebagaimana dikutip dari National Geografic Indonesia, ahli yang bernama Wimpie menyatakan bahwa: "Hormon anti-androgen itu adalah anti-hormon laki-laki. Pemberian obat anti-androgen tidak akan memunculkan efek pada seorang pria akan menjadi feminim,". Namun, kebiri kimiawi menimbulkan efek negatif berupa penuaan dini pada tubuh. Cairan anti-androgen diketahui akan mengurangi kepadatan tulang sehingga risiko tulang keropos atau osteoporosis meningkat. Anti-androgen juga mengurangi massa otot, yang memperbesar kesempatan tubuh menumpuk lemak dan kemudian meningkatkan risiko penyakit jantung dan pembuluh darah. ${ }^{25}$ Proses kebiri kimia dapat melumpuhkan organ sehingga dapat disebut sebagai penyiksaan.

Berdasarkan penjelasan di atas menunjukan bahwa hukum kebiri banyak menimbulkan efek negatif. Pelaksanaan hukum kebiri merupakan sebuah tindakan kekerasan dan dianggap bertentangan dengan UUD NRI yakni pada Pasal 28 G ayat 2 yang berbunyi "setiap orang berhak untuk bebas dari penyiksaan yang merendahkan derajat martabat manusia dan berhak memperoleh suaka politik dari Negara lain". Serta Pasal 33 ayat 1 Undang-undang No 39 Tahun 1999 tentang Hak asasi Manusia yang menyatakan "setiap orang berhak untuk bebas dari penyiksaan, penghukuman, atau perlakuan yang kejam, tidak manusiawi, merendahkan derajat dan martabat kemanusiaanya".

Indonesia juga telah meratifikasi aturan Konvensi yang Menentang Penyiksaan dan Perlakuan atau Hukuman lain yang Kejam, Tidak Manusiawi atau Merendahkan Martabat Manusia sebagaimana telah diadopsi oleh Majelis Umum Perserikatan Bangsa-bangsa (PBB) dalam Resolusinya No. 39/46 tanggal 10 Desember 1984 dan mulai diberlakukan tanggal 26 Juni 1987. Pada Pasal 7 dalam Kovenan ini mengatur

24 Lidya, S. W. Pengebirian Sebagai Upaya Perlindungan Anak Dari Kekerasan Seksual, InfoSingkat Hukum, 20 (7)

25 Bestari Kumala Dewi. (2016 Mei 27). Ini efek hukuman kebiri kimiawi pada tubuh. National Geografic Indonesia 
dengan sangat jelas konsern tentang perlindungan manusia dari ancaman penyiksaan yang dilakukan pihak lain: "Tidak seorangpun boleh dikenai penyiksaan, atau perlakuan atau hukuman yang keji, tidak manusiawi atau merendahkan martabatnya, khususnya tidak seorangpun, tanpa persetujuannya secara sukarela dapat dijadikan eksperimen medis atau ilmiah".

Dari ketentuan Pasal diatas menunjukan bahwa setiap orang berhak bebas dari hukuman yang tidak manusiawi dan merendahkan derajat dan martabat kemanusiaan. Hukum kebiri kimia yang diterapkan hanya berimplikasi pada pembalasan dan penyiksaan terhadap pelaku. Sebagaimana dijelaskan pada pasal 1 ketentuan umum angka 4 Undang-Undang No 39 Tahun 1999 tentang Hak Asasi Manusia yang dimaksud dengan penyiksaan adalah setiap perbuatan yang dilakukan dengan sengaja, sehingga menimbulkan rasa sakit atau penderitaan yang hebat, baik jasmani, maupun rohani."

Pelaksanaan kebiri bisa membuat pelaku justru tidak menjadi lebih baik, tapi malah membuat pelaku hilang kepercayaan diri dan lebih emosional, para ahli dalam bidang kesehatan menolak adanya hukuman kebiri karena hukuman kebiri justru malah membuat sifat agresif pada pelaku serta tidak bisa menjamin terunglangnya lagi tindak kejahatan seksual karena memory seksualnya masih melekat di pikiran pelaku, walaupun hormon testosteronnya menurun, sehingga dikhawatirkan malah menimbulkan tindak pidana baru.

Adapun pandangan Komnas HAM terkait penerapan hukuman kebiri kima bagi pelaku kekerasan seksual yaitu :26

1. Pemberian hukuman melalui pengebirian dapat dikualifikasi sebagai penghukuman keji dan tidak manusiawi yang dengan demikian tidak sesuai dengan konstitusi dan komitmen indonesia dalam bidang hak asasi manusia. Ketentuan pasal 28G ayat (2) konstitusi indonesia menyatakan bahwa "setiap orang berhak untuk bebas dari penyiksaan dan perlakuan yang merendahkan derajat martabat manusia". Dengan demikian hak tersebut bersifat konstitusional dan pemajuan, perlindungan serta pemenuhan menjadi komitmen konstitusional pula.

2. Pemberian hukuman tambahan dengan pengebirian ( baik kimiawi maupun dengan operasi medis), dapat pula dikualifikasikan sebagai pelanggaran hak yaitu pelanggaran hak atas persetujuan tindakan medis dan hak perlindungan atas integritas fisik dan mental seseorang.

26 Komisi Nasional Hak Asasi Manusia. Keterangan Pers Pandangan Komnas HAM mengenai Hukuman Kebiri Bagi Pelaku Kejahatan Seksual. Retrieved from https://www.komnasham.go.id/files/20160215-keterangan-pers-pandangan-komnas 
3. Masukan dari para dokter, ahli hukum dan kriminologi menyatakan sebab kekerasan seksual bukan hanya bersifat medis namun juga psikologis dan sosial. Tindakan kekerasan seksual bukan hanya penetrasi alat kelamin semata. Dalam hal ini, selain hukuman berdasarkan Undang-Undang yang ada, yang harus diberikan adalah upaya pemulihan melalui rehabilitasi secara menyeluruh baik medis, psikologis, dan sosial dengan tetap berpedoman pada hak asasi manusia.

4. Perppu tentang pemberian hukuman kebiri sebaiknya dipertimbangkan kembali dan tidak diterbitkan. Komnas HAM memandang bahwa penanganan kejahatan seksual terhadap anak, dalam hal ini juga perempuan meminta sebuah tindakan menyeluruh dan konsisten serta tidak hanya berpusat pada penghukuman namun juga rehabilitasi dan tindakan pencegahan seperti pengembangan system perlindungan sosial terhadap anak (misalnya komunitas ramah anak dan juga perempuan, keterbukaan informasi tentang para pelaku) ataupun melalui pendidikan dan peningkatan pemahaman mengenai reproduksi. Hal ini, dapat dilakukan dengan melaksanakan Inpres No. 5 tahun 2014 tentang Gerakan Nasional Anti Kejahatan Seksual Terhadap Anak, instrumen yang ada lainnya ataupun memperkuatnya. Kiranya hal ini dapat menjadi perhatian utamanya Penyebab kekerasan seksual bukan hanya bersifat medis namun juga psikologis dan sosial. Tindakan kekerasan seksual bukan hanya sekedar rusaknya alat kelamin semata. Oleh sebab itu hukuman yang berlaku berdasarkan UndangUndang, tetap harus memperhatikan upaya pemulihan melalui rehabilitasi secara menyeluruh baik medis, psikologis, dan sosial dengan tetap berpedoman pada hak asasi manusia. ${ }^{27}$

\section{KESIMPULAN}

Dalam menegakkan keadilan, khususnya kasus paedofilia atau pemerkosaan anak yang sangat brutal terhadap kemanusiaan dan cenderung berulang, Hakim dapat menambahkan hukuman kebiri kimia. Penjatuhan hukuman berupa pidana kebiri kimia seperti yang dijatuhkan pada M.Aris pelaku pelecehan seksual pada anak di Mojokerto beberapa waktu lalu merupakan suatu bentuk langkah mewujudkan adanya upaya dari penegak hukum untuk memberikan perlindungan hukum bagi anak sebagai korban dan juga sebuah langkah tegas yang diambil untuk memberikan efek jera bagi pelaku pelecehan seksual pada anak. Pidana kebiri kimia merupakan sebuah langkah tepat, selain guna memberikan perlindungan hukum bagi anak sebagai korban dan efek jera bagi pelakunya, pidana kebiri kimia juga sebuah bentuk

27 Arif, H. (2017). Rekonstruksi Hukum Tentang Hukuman Kebiri Bagi Pelaku Tindak Pidana Pelecehan Seksual (Kajian Analisis Yuridis-Sosiologis PERPPU No. 1 Tahun 2016 Dalam Perspektif Kriminologi Hukum). Khazanah: Jurnal Studi Islam dan Humaniora, 14(1), 110-133 
pencegahan agar tidak kembali terjadi kasus kasus serupa yang menimpa anak sebagai korbannya. Sehubungan dengan tugas, fungsi dan wewenang tenaga medis atau kesehatan (dokter) yang adalah penyembuhan dan penghormatan hidup manusia secara alami, maka organisasi profesi telah mengeluarkan fatwa MKEK PB IDI No. 1 Tahun 2016 yang pada prinsipnya bahwa: Tugas yang bertentangan dengan penyembuhan adalah bukan tugas profesi dokter.

Bila Hakim benar-benar memutuskan hukuman tambahan berupa kebiri kimia, maka tugas tersebut agar diperankan eksekusinya oleh pihak yang berwenang sebagai eksekutor seperti pada lazimnya Ilmu kedokteran sangat memuliakan kesehatan siapa pun sebagai hak asasi manusia, karenanya para dokter harus menyadari tugasnya untuk mencegah, mendiagnosis, dan mengobati penyakit.

Dengan demikian profesi kedokteran dapat tetap menghormati keputusan hukum yang ada tanpa harus mencederai sumpah profesinya. Faktor sarana atau fasilitas, hambatan ini menjadi pertimbangan khusus bagi Hakim dalam membrikan sanksi pidana keberi selain terbentur oleh para pendapat yang tidak mendukung masalah sanksi ini pun terbentur oleh pada eksekutor ya itu peran dokter dalam menyuntikan kebiri kimiawi terhadap pelaku karena dokter memiliki kode etik kedokteran dan ikatan dokter Indonesia (IDI) yang tidak mengizinkan memberikan sanksi kebiri kimiawi karna mereka berpendapat bahwa hal tersebut tidak boleh dilakukan karena menyalahi aturan dokter yang seharusnya melakukan tindakan penyembuhan tetapi dalam hal ini dokter di tuntut melakukan perbuatan yang menciderai kesehatan pada manusia walau senyata nya hal ini di atur oleh UndangUndang Nomor 17 tahun 2016 tentang Penetapan Perpu 1 tahun 2016 tentang Perubahan Kedua atas UU 23 tahun 2002 tentang Perlindung Anak.

\section{E. DAFTAR PUSTAKA}

\section{Buku-Buku}

S. Susanto dan Sukinta, 2006, Hukum dan HAM. Semarang.

S. W. Lidya, 2007, Pengebirian Sebagai Upaya Perlindungan Anak Dari Kekerasan Seksual, InfoSingkat Hukum

Soekanto Soerjono dkk,2003, Penelitian Hukum Normatif; Suatu Tinjauan Singkat, PT Raja Grafindo Persada, Jakarta.

Waluyo Bambang, 2002, Penelitian Hukum Dalam Praktek, Sinar Grafika, Edisi 1 Cetakan 3,Jakarta,

\section{Peraturan Perundang-Undangan}


Undang-Undang Republik Indonesia Nomor 1 Tahun 1946 Tentang Peraturan Hukum Pidana

Undang-Undang Republik Indonesia Nomor 8 Tahun 1981 Tentang Hukum Acara

Pidana, Lembar Negara Republik Indonesia Tahun 1981 Nomor 76, Tambahan Lembar Negara Republik Indonesia Nomor 3209

Undang-Undang Republik Indonesia Nomor 36 Tahun 2009 Tentang Kesehatan, Lembar Negara Republik Indonesia Tahun 2009 Nomor 144, Tambahan Lembar Negara Republik Indonesia Nomor 5063

Undang-Undang Republik Indonesia Nomor 35 Tahun 2014 Tentang Perubahan Atas Undang-Undang Republik Indonesia Nomor 23 Tahun 2002 Tentang Perlindungan Anak, Lembar Negara Republik Indonesia Tahun 2014 Nomor 297, Tambahan Lembar Negara Republik Indonesia Nomor 5606

Undang-Undang Republik Indonesia Nomor 17 Tahun 2016 Tentang Penetapan Peraturan Pemerintah Pengganti Undang-Undang Nomor 1 Tahun 2016 Tentang Perubahan Kedua Atas Undang-Undang Nomor 23 Tahun 2002 Tentang Perlindungan Anak Menjadi Undang-Undang, Lembaran Negara Republik Indonesia Tahun 2016 Nomor 237, Tambahan Lembaran Negara Republik Indonesia Nomor 5946

\section{Peraturan Pemerintah Pengganti Undang-Undang (Perpu)}

Peraturan Pemerintah Pengganti Undang-Undang Republik Indonesia Nomor 1 Tahun 2016 Tentang Perubahan Kedua Atas Undang-Undang Nomor 23 Tahun 2002 Tentang Perlindungan Anak, Lembaran Negara Republik Indonesia Tahun 2016 Nomor 123, Tambahan Lembaran Negara Republik Indonesia Nomor 5894

Fatwa Majelis Kehormatan Etik Kedokteran Indonesia nomor 1 tahun 2016.

4. Sumber Penelitian/ Jurnal Hukum/ Makalah

H. Arif, (2017). Rekonstruksi Hukum Tentang Hukuman Kebiri Bagi Pelaku Tindak Pidana PelecehanSeksual (Kajian Analisis Yuridis-Sosiologis PERPPU No. 1 Tahun 2016 Dalam Perspektif Kriminologi Hukum). Khazanah: Jurnal Studi Islam dan Humaniora,

Qur'aini Mardiya Nuzul, 2017, Jurnal Konstitusi Penerapan Hukuman Kebiri Kimia Bagi Pelaku Kekerasan Seksual Implementation of Chemical Castration PunishmentFor Sexual Offender, Pusat P4TIK Mahkamah Konstitusi RI, Volume 14, Nomor 1, Jakarta.

Soetedjo,dkk, 2018, Jurnal Etika Kedokteran Indonesia Tinjauan Etika Dokter sebagai Eksekutor Hukuman Kebiri, Vol 2, No. 2. 


\section{Sumber Internet}

A.Rachmaningtyas, 2016, Tugas dokter menyembuhkan alasan IDI tolak hukuman kebiri dinilai wajara

Alayidrus Fadiah, 2019, http://www.antaranews.com/berita/566611/wapresmenghormati-keputusan-idi-tolak-eksekusi-kebiri

II Tisnadibrata, 2018, IDI tolak hukum kebiri

Maharani, Dian, 2015, Yang Terjadi Jika Seseorang Dihukum Kebiri. www.kompas.com

Komisi Nasional Hak Asasi Manusia. Keterangan Pers Pandangan Komnas HAM mengenai Hukuman Kebiri Bagi Pelaku Kejahatan Seksual. Retrieved from https://www.komnasham.go.id/files/20160215-keterangan-perspandangan-komnas

http://www.idionline.org/page/4/?s=kebiri)

http://forumkeadilan.co/hukum/10-alasan-hukuman-kebiri-tidak-efektif-bagipelaku-kejahatan-seks/)

Liputuan6.com, Senin, 26 Agustus 2019. 